\title{
Assessing gaps in reporting non-target mortality in island rodent eradication operations
}

\author{
Simon Ward • Auriel M. V. Fournier (1) - Alexander L. Bond $(1)$
}

Received: 5 October 2018/Accepted: 7 June 2019/Published online: 25 June 2019

(C) The Author(s) 2019

\begin{abstract}
Eradicating invasive species is a key part of island restoration, and can reverse the devastating impacts on native biota. Rodents are one of the most widespread invasive species, found on $80 \%$ of oceanic island systems, but have been removed from hundreds of islands through the application of anticoagulanttreated cereal bait. While such eradication operations are often net positive events for island ecosystems over the long-term, some native biota are also susceptible, resulting in short-term non-target mortality. One of the most widely distributed groups of birds, rails and allies (Rallidae) are highly adaptable, often endemic, and are known often to suffer mortality
\end{abstract}

Electronic supplementary material The online version of this article (https://doi.org/10.1007/s10530-019-02032-7) contains supplementary material, which is available to authorized users.

S. Ward

School of Biological and Chemical Sciences, Queen Mary University of London, Mile End Road, London E1 4NS, UK

A. M. V. Fournier

Mississippi State University, 1815 Popps Ferry Road,

Biloxi, MS 39532, USA

Present Address:

A. M. V. Fournier

Forbes Biological Station-Bellrose Waterfowl Research Center, Illinois Natural History Survey, Prairie Research Institute, University of Illinois at Urbana-Champaign, Havana, IL 62644, USA during rodent eradication operations, to varying degrees. Our goal was determine if the year of eradication or the size of the island predicted whether non-target mortalities were reported, including those that were true absences of mortality. We examined 122 eradication operations on 81 islands with rails present from 1983 to 2015 , and found $78 \%$ with no reported information on non-target mortality using our search criteria. We found non-target mortality reporting has decreased over time, and there was no relationship with island size. Post-operational monitoring of eradication operations should thoroughly record non-target mortality to improve our understanding of factors affecting non-target mortality, and the efficacy of mitigation measures.

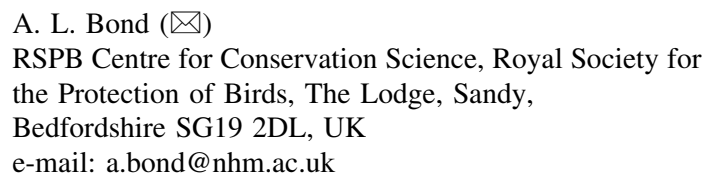

A. L. Bond

Bird Group, Department of Life Sciences, The Natural

History Museum, Akeman Street, Tring,

Hertfordshire HP23 6AP, UK 
Keywords Invasive species · Island restoration · Non-target $\cdot$ Rallidae $\cdot$ Rodent

\section{Introduction}

The removal of invasive, alien, or introduced species has become a frequently used tool in the restoration of island ecosystems (Atkinson 2001; Bellingham et al. 2010; Rauzon 2007; Russell and Holmes 2015). Introduced mammals, in particular cats (Felis catus), house mice (Mus musculus) and rats (Rattus exulans, $R$. norvegicus, and $R$. rattus), are among the most detrimental (Angel et al. 2009; Jones et al. 2008; Medina et al. 2011), and have been the subject of hundreds of eradication operations in the last 50 years (DIISE 2016; Howald et al. 2007; Russell and Broome 2016).

Rodents in particular have invaded more than 1000 islands, and are now a globally-distributed invasive species and found on many oceanic and coastal islands (Atkinson 1985). Introduced rodents can have destructive effects on native biota, and can alter the ecosystem structure and function of islands (Blackburn et al. 2004; Croll et al. 2005; Jones et al. 2008; Towns et al. 2006). Because of islands' importance for biodiversity, and the devastating effects of introduced rodents (Holmes et al. 2019), conservationists have undertaken hundreds of eradication operations worldwide to remove introduced rodents from islands, and implemented biosecurity measures to prevent reinvasion (Harris et al. 2012; Howald et al. 2007; Russell and Broome 2016; Springer 2011; Towns and Broome 2003).

The most common eradication method is the use of pelletized cereal bait. Pelletizied bait contains an anticoagulant rodenticide and is distributed in a variety of manners dependant on the size and structure of the island, and government regulations (Russell et al. 2016). These methods include bait distributed in bait stations laid out on a grid pattern, or broadcast by hand or aerial application techniques. This approach has been effective in temperate zones at removing invasive rodents from hundreds of islands across the world (Howald et al. 2007; Russell and Holmes 2015) resulting in significant benefits to native biodiversity (Brooke et al. 2018; Jones 2010; Jones et al. 2016; Lavers et al. 2010). Such eradication operations, however, often incur non-target mortality, in which animals not considered the target species are killed unintentionally (Eason et al. 2002; Hoare and Hare 2006). This involves either the direct consumption of the bait (primary poisoning) or through secondary poisoning by eating contaminated prey. In some cases, this can be mitigated by keeping a population of susceptible individuals in captivity, or translocating individuals to another island, for the duration of bait availability (Oppel et al. 2016a). A fundamental element in such restoration efforts is that the ecological benefits must exceed the costs, which includes the risks to non-target species, and of the mitigation measures themselves (Bomford and O'Brien 1995; Broome et al. 2014).

Rails (Gruiformes: Rallidae) consist of approximately 140 extant species distributed globally, that range in body size from $\sim 30$ to $>3000 \mathrm{~g}$ (Ripley 1977; Taylor and van Perlo 1998). They occupy a wide range of habitats including wetlands, freshwater and saltwater marshes, mangroves, tropical forests, and grasslands, as well as small oceanic islands, where they have evolved into distinct lineages (Livezey 1998; Taylor and van Perlo 1998). These species are often flightless, and have adapted to be generalist forest species due to the lack of mammal predators and in order to balance energy costs (Olson 1973; Ripley and Beehler 1985). More than 60 rail species have gone extinct since 1000 CE (Hume and Walters 2012), often because of anthropogenic factors (Ripley 1977).

The combination of a highly plastic and adaptable diet, and the frequent evolution of flightlessness, particularly on islands formerly free of native predators, makes rails susceptible to non-target mortality during rodent eradiation operations. Primary and secondary poisoning can result in population level non-target mortality and possibly local extirpation or extinction (e.g., Dowding et al. 1999; Oppel et al. 2016a, b; Vyas 2017; Wanless et al. 2010). Despite this, there is little information on the susceptibility of rails, or other non-target taxa, during rodent eradication operations, which limits our ability to assess tradeoffs of future eradication efforts.

Our objectives were to: (1) assess the extent to which rail populations have been affected by rodent eradication operations, (2) examine the degree of reporting for non-target mortality using rails as exemplars, and (3) determine whether operation characteristics influence the probability of mortality 
being reported. We predicted that improved awareness around non-target mortality would result in greater reporting over time, and that smaller islands where a greater proportion of the island could be searched would be more likely to report the presence or absence of non-target mortality.

\section{Methods}

We collated available data on rodent eradications on islands, and the distribution of rails using publicly available sources, and expert opinion. Data on rodent eradication attempts were gathered from the Database of Island Invasive Species Eradication (DIISE 2016) through September 2015. This database provided a list of references for island rodent eradications which we consulted to obtain details on bait type, bait concentration, and delivery method, all of which can influence non-target mortality (Eason et al. 2002). We compiled distribution data of rail species on islands that have had rodent eradications from the Birdlife International Data Zone (http://www.birdlife. org/datazone/species), from eradication operational reports, and in-country experts. When range maps provided ambiguous information about rail diversity on islands, we consulted with in-country experts from an established network of island restoration scientists and practitioners. The combined list of eradication operations on islands with rails was then used to then gather detailed information of each operation, including the method of bait delivery (aerial, bait station, hand broadcast), and non-target rail mortalities from published papers, operational reports, and government documents. We excluded bait type, and bait concentration from analyses as many values were represented by only one or a few eradication operations. Data on rails' predominant diet (herbivorous, omnivorous, insectivorous), and IUCN Red List status was collected from the literature (Birdlife International 2017; Ripley 1977; Ripley and Beehler 1985; Taylor and van Perlo 1998).

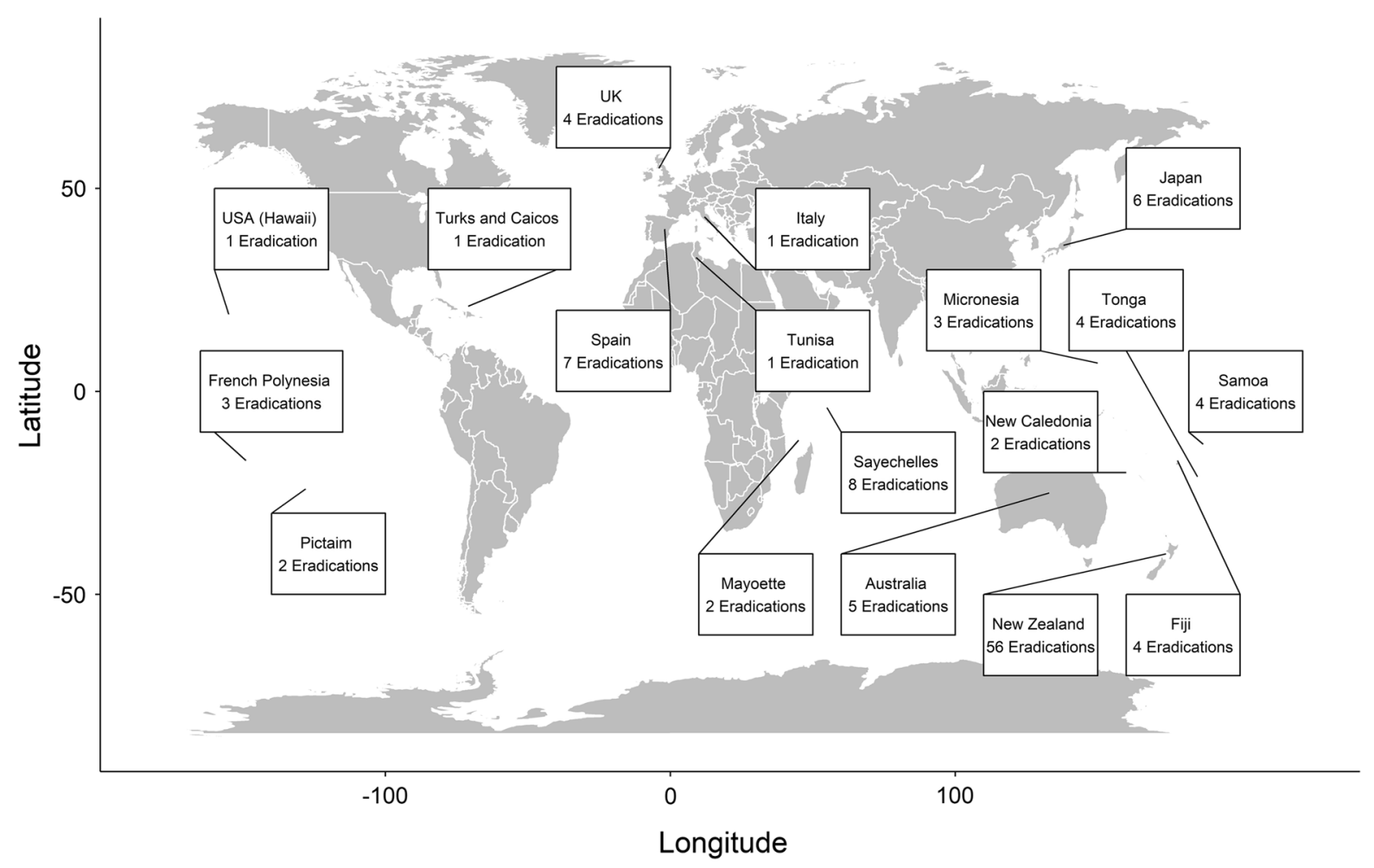

Fig. 1 Map of countries where rodent eradication operations occurred in the presence of rails 
Table 1 Different rail species listed with various aspects of their biology and the number of instances of known and unknown mortality during rat eradications

\begin{tabular}{|c|c|c|c|c|c|c|c|}
\hline Species & $\begin{array}{l}\text { Scientific } \\
\text { name }\end{array}$ & $\begin{array}{l}\text { Average } \\
\text { size }(g)\end{array}$ & $\begin{array}{l}\text { Flight } \\
\text { ability }\end{array}$ & $\begin{array}{l}\text { Predominant } \\
\text { diet }\end{array}$ & $\begin{array}{l}\text { IUCN Red } \\
\text { List status }\end{array}$ & $\begin{array}{l}\text { Number of known } \\
\text { mortality cases }\end{array}$ & $\begin{array}{l}\text { Number of unknown } \\
\text { mortality cases }\end{array}$ \\
\hline Clapper rail & $\begin{array}{l}\text { Rallus } \\
\quad \text { crepitans }\end{array}$ & $160-400$ & Flight & Insectivorous & $\begin{array}{l}\text { Least } \\
\text { concern }\end{array}$ & 0 & 1 \\
\hline $\begin{array}{l}\text { Western } \\
\text { water rail }\end{array}$ & $\begin{array}{l}\text { Rallus } \\
\text { aquaticus }\end{array}$ & $92-164$ & Flight & Omnivorous & $\begin{array}{l}\text { Least } \\
\text { concern }\end{array}$ & 0 & 10 \\
\hline Lewin's rail & $\begin{array}{l}\text { Lewinia } \\
\text { pectoralis }\end{array}$ & $63-112$ & Flight & Insectivorous & $\begin{array}{l}\text { Least } \\
\text { concern }\end{array}$ & 1 & 1 \\
\hline Weka & $\begin{array}{l}\text { Gallirallus } \\
\text { australis }\end{array}$ & $430-1400$ & Flightless & Omnivorous & Vulnerable & 13 & 15 \\
\hline $\begin{array}{l}\text { Buff-banded } \\
\text { rail }\end{array}$ & $\begin{array}{r}\text { Hypotaenidia } \\
\text { philippensis }\end{array}$ & 170 & Flight & Insectivorous & $\begin{array}{l}\text { Least } \\
\text { concern }\end{array}$ & 9 & 22 \\
\hline Corncrake & Crex crex & $145-165$ & Flight & Insectivorous & $\begin{array}{l}\text { Least } \\
\text { concern }\end{array}$ & 0 & 2 \\
\hline $\begin{array}{l}\text { Henderson } \\
\text { crake }\end{array}$ & Zapornia atra & $66-88$ & Flightless & Insectivorous & Vulnerable & 1 & 0 \\
\hline $\begin{array}{l}\text { Spotless } \\
\text { crake }\end{array}$ & $\begin{array}{l}\text { Zapornia } \\
\text { tabuensis }\end{array}$ & 45 & Flight & Omnivorous & $\begin{array}{l}\text { Least } \\
\text { concern }\end{array}$ & 5 & 10 \\
\hline $\begin{array}{l}\text { White- } \\
\text { breasted } \\
\text { waterhen }\end{array}$ & $\begin{array}{l}\text { Amaurornis } \\
\text { phoenicurus }\end{array}$ & $166-328$ & Flight & Insectivorous & $\begin{array}{l}\text { Least } \\
\text { concern }\end{array}$ & 0 & 6 \\
\hline $\begin{array}{l}\text { White- } \\
\text { browed } \\
\text { crake }\end{array}$ & $\begin{array}{l}\text { Amaurornis } \\
\text { cinerea }\end{array}$ & $40-63$ & Flight & Omnivorous & $\begin{array}{l}\text { Least } \\
\text { concern }\end{array}$ & 0 & 4 \\
\hline $\begin{array}{l}\text { Purple } \\
\text { swamphen }\end{array}$ & $\begin{array}{l}\text { Porphyrio } \\
\text { porphyrio }\end{array}$ & 880-1090 & Flight & Omnivorous & $\begin{array}{l}\text { Least } \\
\text { concern }\end{array}$ & 10 & 13 \\
\hline $\begin{array}{l}\text { South Island } \\
\text { takahe }\end{array}$ & $\begin{array}{l}\text { Porphyrio } \\
\text { hochstetteri }\end{array}$ & $2000-3500$ & Flightless & Herbivorous & Endangered & 3 & 6 \\
\hline $\begin{array}{l}\text { Allen's } \\
\text { gallinule }\end{array}$ & $\begin{array}{l}\text { Porphyrio } \\
\text { alleni }\end{array}$ & 82 & Flight & Insectivorous & $\begin{array}{l}\text { Least } \\
\text { concern }\end{array}$ & 0 & 2 \\
\hline $\begin{array}{l}\text { Common } \\
\text { moorhen }\end{array}$ & $\begin{array}{l}\text { Gallinula } \\
\text { chloropus }\end{array}$ & $192-493$ & Flight & Insectivorous & $\begin{array}{l}\text { Least } \\
\text { concern }\end{array}$ & 2 & 24 \\
\hline $\begin{array}{l}\text { Common } \\
\text { gallinule }\end{array}$ & $\begin{array}{r}\text { Gallinula } \\
\text { galeata }\end{array}$ & $310-456$ & Flight & Herbivorous & $\begin{array}{l}\text { Least } \\
\text { concern }\end{array}$ & 0 & 1 \\
\hline $\begin{array}{l}\text { Common } \\
\text { coot }\end{array}$ & Fulica atra & 585-1100 & Flight & Omnivorous & $\begin{array}{l}\text { Least } \\
\text { concern }\end{array}$ & 0 & 11 \\
\hline $\begin{array}{l}\text { Hawaiian } \\
\text { coot }\end{array}$ & Fulica alai & $450-900$ & Flight & Omnivorous & Vulnerable & 0 & 1 \\
\hline $\begin{array}{l}\text { American } \\
\text { coot }\end{array}$ & $\begin{array}{l}\text { Fulica } \\
\text { americana }\end{array}$ & 600-1000 & Flight & Herbivorous & $\begin{array}{l}\text { Least } \\
\text { concern }\end{array}$ & 0 & 1 \\
\hline
\end{tabular}

Taxonomy sequence follows (del Hoyo and Collar 2014)

\section{Statistical analyses}

To determine whether the size of an island or the year in which the eradication took place could predict whether non-target mortality was reported (including when no mortality was observed, i.e., a true absence), we used logistic regression with a binomial error distribution and logit link function. We log-transformed island area as one island was several orders of magnitude larger than the others. Analyses were considered significant when $p<0.05$, and we present parameter estimates with their associated standard 
errors $(\beta \pm \mathrm{SE})$. All analyses were conducted in $\mathrm{R}$ 3.4.4 ( $\mathrm{R}$ Core Team 2018), and the script is provided in the Supplementary Information.

\section{Results}

We found 122 rodent eradication operations on 81 islands in 18 territories from 1983 to 2015 during which rail species were present during eradication operations (Fig. 1, Appendix 1 of electronic supplementary material). Mean island size was $15.4 \mathrm{~km}^{2}$ (0.01-1576.4 $\left.\mathrm{km}^{2}\right)$. These operations overlapped with the distribution of 1-3 rail species per site, and 18 species overall (Table 1). In total, 95 (78\%) eradication operations included no information or no mention of non-target mortality generally, or rail mortality in particular, in any published paper, operational report, or available government document. More recent eradication operations were less likely to report nontarget mortality, and island size was unrelated to whether mortality was reported (Table 2; Fig. 2). One

Table 2 Logistic regression of whether the island size, or the year in which an eradication took place predict whether nontarget rail mortality was reported (including true absences)

\begin{tabular}{lcrl}
\hline Category & $\beta$ estimate & \multicolumn{1}{l}{ SE } & $p$ value \\
\hline Intercept & 159.18 & 63.77 & 0.02 \\
Log [area $(\mathrm{km})]$ & 0.12 & 0.12 & 0.30 \\
Year & -0.08 & -0.03 & 0.01 \\
\hline
\end{tabular}

species was listed as Endangered by IUCN, 3 as Vulnerable and the remainder (14) as least concern.

\section{Discussion}

The success of eradication operations worldwide is built on the shared knowledge of past experiences in the island restoration community (e.g., Veitch et al. 2019). This has included the development of best practices for operations (Broome et al. 2014; Keitt et al. 2015), and open discussions of the challenges associated with such complex projects. Better reporting of non-target mortality can only be beneficial as we collectively seek ways to reduce it in future eradication operations, which requires a strong evidence base. Curiously, more recent operations were less likely to report on the outcome of any searching for non-target mortality, regardless of island size (Table 2). Such information may well exist in permit reports that are not publicly available, or centralized, but the result is the same: the information is not available for practitioners, researchers, and managers. With a greater number of more complex eradication operations on the horizon (including Gough Island, Marion Island, Lord Howe Island, and the Auckland Islands), and greater scrutiny from the general public and statutory authorities around operations (Campbell et al. 2015; Santo et al. 2015; Wilkinson and Priddel 2011), transparency around non-target mortality is also essential to maintaining the integrity of eradications as a conservation tool.

To better support evidence-based decision making for future eradication operations, practitioners should
Fig. 2 Reporting the results of searches for non-target mortality was not a function of island size, but decreased over time
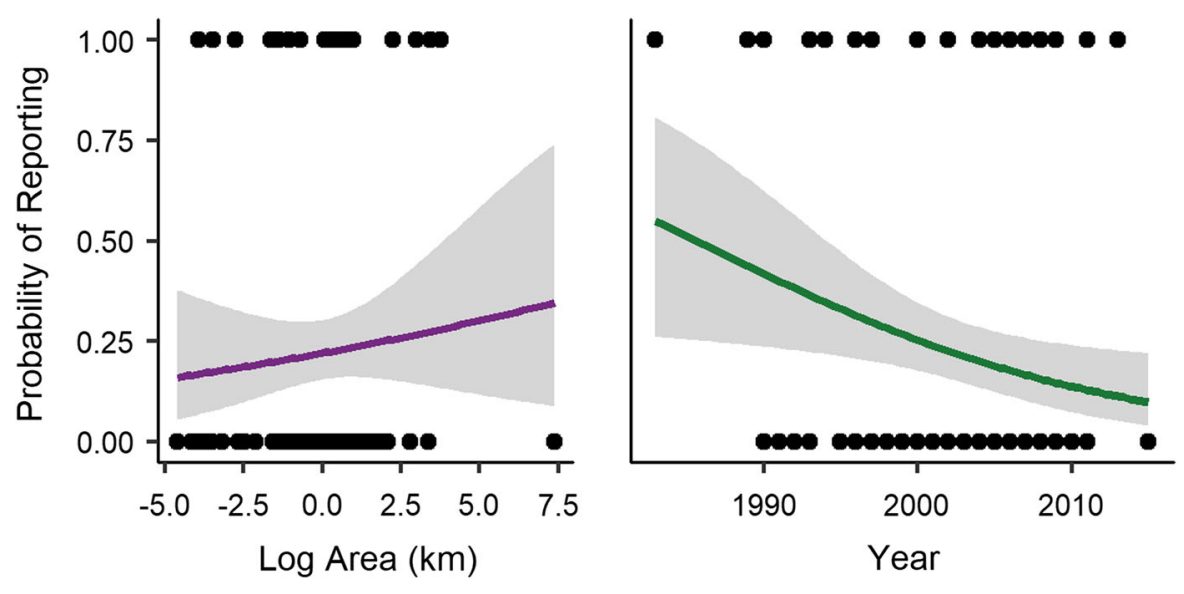
better collect, report, and disseminate information about non-target mortality, including instances where no mortality was observed. We were surprised to find that reporting of non-target mortality has been decreasing over time. While the Database of Island Invasive Species Eradication gathers data about eradications, it does not go into the necessary detail regarding non-target mortalities. To gather non-target mortality information the individual eradication attempt reports had to be used. Reports varied greatly in their level of detail, from full reports of all species affected to no information in the report or no report found. To support our understanding of eradication impacts on non-target species eradication operations should endeavour to assess the pre- and post-operation abundance of non-target species. Not only will more complete documentation demonstrate the efficacy of the eradication in restoring native biota, but it will allow for an assessment of the potential non-target mortality incurred to inform future eradications efforts and necessary mitigation measures. The reporting of non-target mortality is often a condition of government permits for rodent eradication operations, but these documents are not necessarily publicly available, or easily found, thereby impeding analyses such as ours. Eradications that did report mortality often did so without giving a sense of search effort or area, which further complicates synthesis among studies. Reporting should include at least an indication of search effort, the species searched for, area searched (especially if the whole island was not searched for non-target mortality), and the duration of search effort following the eradication operation.

Given that only $22 \%$ of eradication operations reported on non-target rail mortality, we lacked sufficient data to understand which traits might predispose species to being particularly affected by rodent eradications. Equally, we were unable to assess which operational measures, such as bait type, concentration, spreading density, or application method might be associated with a greater probability of rail mortality.

Improved reporting would allow managers, practitioners, and other researchers to better predict the potential effects of rodent eradication operations, particularly when specific data for a given taxon or ecosystem may be lacking (Sutherland et al. 2004). While our work here highlights what is not known about rails, many other native or endemic species could also suffer non-target effects from eradications, and should also be monitored (Pitt et al. 2015). Several, but not all, mitigation measures, including captive holding, have been used successfully (e.g., Oppel et al. 2016a; Wilkinson and Priddel 2011), and the presence of rail populations does not necessarily imply that an eradication operation will encounter significant non-target mortality. Rodent eradications have a long collaborative history which would easily extend to the improved public accessibility of data on non-target impacts, and likely resulting in improved knowledge about the potential impacts of rodent eradications on rail populations, and informing mitigation measures to ensure eradication success while minimising impacts on non-target species.

Acknowledgements We thank C. Miskelly for his help with gathering the distribution of New Zealand rails, and J. Russell for finding many reports pertaining to eradications on New Zealand islands. C. Eizaguirre provided guidance and statistical advice. Comments from N. Holmes, C. Stringer, and two anonymous reviewers improved this manuscript.

Open Access This article is distributed under the terms of the Creative Commons Attribution 4.0 International License (http:// creativecommons.org/licenses/by/4.0/), which permits unrestricted use, distribution, and reproduction in any medium, provided you give appropriate credit to the original author(s) and the source, provide a link to the Creative Commons license, and indicate if changes were made.

Data availability Data and associated R scripts are available on figshare at https://doi.org/10.6084/m9.figshare.7035200.

\section{References}

Angel A, Wanless RM, Cooper J (2009) Review of impacts of the introduced house mouse on islands in the Southern Ocean: are mice equivalent to rats? Biol Invasions 11:1743-1754

Atkinson IAE (1985) The spread of commensal species of Rattus to oceanic islands and their effects on island avifaunas. In: Moors PJ (ed) Conservation of island birds. ICBP Technical Publication No. 3, Cambridge, pp 35-81

Atkinson IAE (2001) Introduced mammals and models for restoration. Biol Conserv 99:81-96

Bellingham PJ, Towns DR, Cameron EK, Davis JJ, Wardle DA, Wilmshurst JM, Mulder CPH (2010) New Zealand island restoration: seabirds, predators, and the importance of history. N Z J Ecol 34:115-136

Birdlife International (2017) IUCN Red List for birds. Downloaded from http://www.birdlife.org on 29 June 2017 
Blackburn TM, Cassey P, Duncan RP, Evans KL, Gaston KJ (2004) Avian extinction and mammalian introductions on oceanic islands. Science 305:1955-1958

Bomford M, O'Brien P (1995) Eradication or control of vertebrate pests? Wildl Soc Bull 23:249-255

Brooke ML, Bonnaud E, Dilley BJ, Flint EN, Holmes ND, Jones HP, Provost P, Rocamora G, Ryan PG, Surman C, Buxton RT (2018) Seabird population changes following mammal eradications on islands. Anim Conserv 21:3-12

Broome KG, Cox A, Golding C, Cromarty P, Bell P, McClellend $P$ (2014) Rat eradication using aerial baiting. Current agreed best practice used in New Zealand (Version 3.0). New Zealand Department of Conservation, Wellington

Campbell KJ, Beek J, Eason CT, Glen AS, Godwin J, Gould F, Holmes ND, Howald GR, Madden FM, Ponder JB, Threadgill DW, Wegmann AS, Baxter GS (2015) The next generation of rodent eradications: innovative technologies and tools to improve species specificity and increase their feasibility on islands. Biol Conserv 185:47-58

Croll DA, Maron JL, Estes JA, Danner EM, Byrd GV (2005) Introduced predators transform subarctic islands from grassland to tundra. Science 307:1959-1961

del Hoyo J, Collar NJ (2014) HBW and Birdlife International illustrated checklist of the Birds of the World. Volume 1: non-passerines. Lynx Edicions, Barcelona

DIISE (2016) The Database of Island Invasive Species Eradications. Island Conservation, Coastal Conservation Action Laboratory UCSC, IUCN SSC Invasive Species Specialist Group. University of Auckland and Landcare Research New Zealand. http://diise.islandconservation.org. Accessed 1 July 2016

Dowding JE, Murphy EC, Veitch CR (1999) Brodifacoum residues in target and non-target species following an aerial poisoning operation on Motuihe Island, Hauraki Gulf, New Zealand. N Z J Ecol 23:207-214

Eason CT, Murphy EC, Wright GRG, Spurr EB (2002) Assessment of risks of brodifacoum to non-target birds and mammals in New Zealand. Ecotoxicology 11:35-48

Harris DB, Gregory SD, Bull LS, Courchamp F (2012) Island prioritization for invasive rodent eradications with an emphasis on reinvasion risk. Biol Invasions 14:1251-1263

Hoare JM, Hare KM (2006) The impact of brodifacoum on nontarget wildlife: gaps in knowledge. N Z J Ecol 30:157-167

Holmes ND, Spatz DR, Oppel S, Tershy B, Croll DA, Keitt B, Genovesi P, Burfield IJ, Will DJ, Bond AL, Wegmann A, Aguirre-Muñoz A, Raine AF, Knapp CR, Hung C-H, Wingate D, Hagen E, Méndez-Sánchez F, Rocamora G, Yuan H-W, Fric J, Millett J, Russell J, Liske-Clark J, Vidal E, Jourdan H, Campbell K, Springer K, Swinnerton K, Gibbons-Decherong L, Langrand O, Brooke ML, McMinn M, Bunbury N, Oliveira N, Sposimo P, Geraldes P, McClelland P, Hodum P, Ryan PG, Borroto-Páez R, Pierce R, Griffiths R, Fisher RN, Wanless R, Pasachnik SA, Cranwell S, Micol T, Butchart SHM (2019) Globally important islands where eradicating invasive mammals will benefit highly threatened vertebrates. PLoS ONE 14:e0212128

Howald GR, Donlan CJ, Galván JP, Russell JC, Parkes J, Samaniego A, Wang Y, Veitch D, Genovesi P, Pascal M, Saunders A, Tershy B (2007) Invasive rodent eradication on islands. Conserv Biol 21:1258-1268
Hume JP, Walters M (2012) Extinct birds. T. \& A.D. Poyser, London

Jones HP (2010) Seabird islands take mere decades to recover following rat eradication. Ecol Appl 20:2075-2080

Jones HP, Tershy B, Zavaleta ES, Croll DA, Keitt BS, Finkelstein ME, Howald GR (2008) Severity of the effects of invasive rats on seabirds: a global review. Conserv Biol 22:16-26

Jones HP, Holmes ND, Butchart SHM, Tershy BR, Kappes PJ, Corkery I, Aguirre-Muñoz A, Armstrong DP, Bonnaud E, Burbidge AA, Campbell K, Courchamp F, Cowan PE, Cuthbert RJ, Ebbert SE, Genovesi P, Howald GR, Keitt BS, Kress SW, Miskelly CM, Oppel S, Poncet S, Rauzon MJ, Rocamora G, Russell JC, Samaniego-Herrera A, Seddon PJ, Spatz DR, Towns DR, Croll DA (2016) Invasive mammal eradication on islands results in substantial conservation gains. Proc Natl Acad Sci USA 113:4033-4038

Keitt BS, Griffiths R, Boudjelas S, Broome KG, Cranwell S, Millett J, Pitt W, Samaniego-Herrera A (2015) Best practice guidelines for rat eradication on tropical islands. Biol Conserv 182:17-26

Lavers JL, Wilcox C, Donlan CJ (2010) Bird demographic responses to predator removal programs. Biol Invasions 12:3839-3859

Livezey BC (1998) A phylogenetic analysis of the Gruiformes (Aves) based on morphological characters, with an emphasis on the rails (Rallidae). Philos Trans R Soc B Biol Sci 353:2077-2151

Medina FM, Bonnaud E, Vidal E, Tershy BR, Zavaleta ES, Donlan CJ, Keitt BS, Le Corre M, Horwath SV, Nogales M (2011) A global review of the impacts of invasive cats on island endangered vertebrates. Glob Change Biol $17: 3503-3510$

Olson SL (1973) Evolution of the rails of the South Atlantic Islands (Aves: Rallidae). Smithson Contrib Zool 152:1-53

Oppel S, Bond AL, Brooke MdL, Harrison G, Vickery JA, Cuthbert RJ (2016a) Temporary captive population and rapid population recovery of an endemic flightless rail after a rodent eradication operation using aerially distributed poison bait. Biol Conserv 204B:442-448

Oppel S, Lavers JL, Bond AL, Harrison G (2016b) Reducing the primary exposure risk of Henderson crakes (Zapornia atra) during aerial broadcast eradication by selecting appropriate bait colour. Wildl Res 43:298-303

Pitt WC, Berentsen AR, Shiels AB, Volker SF, Eisemann JD, Wegmann AS, Howald GR (2015) Non-target species mortality and the measurement of brodifacoum rodenticide residues after a rat (Rattus rattus) eradication on Palmyra Atoll, tropical Pacific. Biol Conserv 185:36-46

R Core Team (2018) R: a language and environment for statistical computing Version 3.4.4 [computer program]. R Foundation for Statistical Computing, Vienna

Rauzon MJ (2007) Island restoration: exploring the past, anticipating the future. Mar Ornithol 35:97-107

Ripley SD (1977) Rails of the world. Goodine, Boston

Ripley SD, Beehler BM (1985) Rails of the world, a compilation of new information, 1975-1983 (Aves: Rallidae). Smithson Contrib Zool 417:1-28

Russell JC, Broome KG (2016) Fifty years of rodent eradications in New Zealand: another decade of advances. N Z J Ecol 40:197-204 
Russell JC, Holmes ND (2015) Tropical island conservation: rat eradication for species recovery. Biol Conserv 185:1-7

Russell JC, Jones HP, Armstrong DP, Courchamp F, Kappes PJ, Seddon PJ, Oppel S, Rauzon MJ, Cowan PE, Rocamora G, Genovesi P, Bonnaud E, Keitt BS, Holmes ND, Tershy BR (2016) Importance of lethal control of invasive predators for island conservation. Conserv Biol 30:670-672

Santo AR, Sorice MG, Donlan CJ, Franck CT, Anderson CB (2015) A human-centered approach to designing invasive species eradication programs on human-inhabited islands. Glob Environ Change 35:289-298

Springer K (2011) Planning processes for eradication of multiple pest species on Macquarie Island-an Australian case study. In: Veitch CR, Clout MN, Towns DR (eds) Island invasives: eradication and management. IUCN, Gland, pp 228-232

Sutherland WJ, Pullin AS, Dolman PM, Knight TM (2004) The need for evidence-based conservation. Trends Ecol Evol 19:305-308

Taylor B, van Perlo B (1998) Rails: a guide to the rails, crakes, gallinules and coots of the world. Pica Press, Sussex

Towns DR, Broome KG (2003) From small Maria to massive Campbell: forty years of rat eradications from New Zealand islands. N Z J Zool 30:377-398
Towns DR, Atkinson IAE, Daugherty CH (2006) Have the harmful effects of introduced rats on islands been exaggerated? Biol Invasions 8:863-891

Veitch CR, Clout MN, Martin AR, Russell JC, West CJ (2019) Island invasives: scaling up to meet the challenge. In: Proceedings of the international conference on island invasives 2017. Occasional paper of the IUCN Species Survival Commission No. 62. IUCN, Gland, Switzerland

Vyas NB (2017) Rodenticide incidents of exposure and adverse effects on non-raptor birds. Sci Total Environ 609:68-76

Wanless RM, Cooper J, Slabber M, Ryan PG (2010) Risk assessment of birds foraging terrestrially at Marion and Gough Islands to primary and secondary poisoning by rodenticides. Wildl Res 37:524-530

Wilkinson IS, Priddel D (2011) Rodent eradication on Lord Howe Island: challenges posed by people, livestock, and threatened endemics. In: Veitch CR, Clout MN (eds) Island invasives: eradication and management. IUCN, Gland, pp 508-514

Publisher's Note Springer Nature remains neutral with regard to jurisdictional claims in published maps and institutional affiliations. 